\title{
Teachers Working in Special Schools in Scotland Acting with Practical Wisdom: Supporting Children with Additional Needs in COVID-19 Lockdown
}

\author{
Daniela Mercieca (D), Duncan P. Mercieca *(D) and Kumara Ward (D) \\ School of Education and Social Work, University of Dundee, Dundee DD1 4HN, UK; \\ dmercieca001@dundee.ac.uk (D.M.); KWard001@dundee.ac.uk (K.W.) \\ * Correspondence: dmercieca002@dundee.ac.uk
}

Citation: Mercieca, D.; Mercieca, D.P.; Ward, K. Teachers Working in Special Schools in Scotland Acting with Practical Wisdom: Supporting Children with Additional Needs in COVID-19 Lockdown. Educ. Sci. 2021, 11, 569. https://doi.org/10.3390/ educsci11100569

Academic Editor: Debra Costley

Received: 12 August 2021

Accepted: 17 September 2021

Published: 23 September 2021

Publisher's Note: MDPI stays neutral with regard to jurisdictional claims in published maps and institutional affiliations.

Copyright: (C) 2021 by the authors. Licensee MDPI, Basel, Switzerland. This article is an open access article distributed under the terms and conditions of the Creative Commons Attribution (CC BY) license (https:// creativecommons.org/licenses/by/ $4.0 /)$.

\begin{abstract}
The COVID-19 lockdown has substantially disrupted the established facets of teacher engagement with their students, and, given the significance of this multidimensional interaction, it brings into question what we know as teachers' identity. The lockdown has offered a dilemmatic context where the processes of teaching and learning and being(s) a teacher are being re-visited and re-negotiated. This paper looks specifically at the perceptions of two teachers of their lockdown experience working within a special education context in Scotland, supporting children with disabilities and/or learning difficulties while at home. The question that this paper addresses is: what is the understanding of these two teachers of their role in a specialised educational context while in COVID-19 lockdown? This paper uses 'practical wisdom' (also known as phronêsis) as its theoretical basis, where the focus is on teachers' judgements at precisely those moments where guidelines and procedures are unclear, and the criteria open to multiple interpretations. The COVID-19 pandemic certainly provided this context. Richard Smith's interpretation of phronêsis as 'attentiveness' are central to this paper. In-depth interviews carried out with teachers are analysed through this theoretical framework and two themes are discussed.
\end{abstract}

Keywords: COVID-19 pandemic; Scotland; teacher judgement; practical wisdom (phronêsis); attentiveness

\section{Introduction}

Impact on education: While reliable figures on students with disabilities are not yet available, it is likely that the current crisis has exacerbated their exclusion from education. As detailed in the policy brief on the impact of COVID-19 on children (see United Nations, 2020a), students with disabilities are least likely to benefit from distance-learning solutions. Lack of support, access to the internet, accessible software and learning materials are likely to deepen the gap for students with disabilities [1] p. 6.

The above quote, taken from the United Nations [1] policy brief on 'DisabilityInclusion response to COVID-19', captures the complexity of the engagement of students with disability with learning during the COVID-19 lockdown. This paper is situated within this international discourse, while focusing on Scotland. This paper looks specifically at the perceptions of two teachers of their lockdown experience while working within a special education context in Scotland, supporting children with disabilities and/or learning difficulties while at home. The question that this paper addresses is:

What is the understanding of these two teachers of their role in a specialised educational context while in COVID-19 lockdown?

This focus is not matched by other research to our knowledge, in the UK or beyond, as it sheds light on the lived experiences of teachers working in special educational contexts during lockdown. Their voices do not always feature in mainstream teacher research. While 
the paper focuses on two teachers working within Scotland, some of the ideas will resonate with other teachers who work with children with Additional Support Needs internationally.

While the literature exploring the impact of COVID-19 on education is rapidly increasing, the focus on children with addition support needs and disabilities and their families is still limited (see European Journal of Special Needs Education, Volume 36, Issue 1 (2021) Impact of COVID-19 on special education). Fiona Couper-Kenney and Sheila Riddell's [2] research on mothers' perspectives in Scotland argue that since education and care services were suddenly withdrawn in the first lockdown, existing inequalities were exacerbated, such as unequal access to IT, varying levels of support and differences in family resources. However, some families also reported some positive experiences, such as enjoying more time together and a release from school-generated stress. Una O'Connor et al. [3] surveyed parents of children attending special schools in Northern Ireland about their experiences during school closures relating to COVID-19. The paper describes parents' experiences relative to their child's needs, family circumstances and societal expectations, and the intersection of these with teacher relationships and the wider school community.

While both these researches mention children attending special education, the data gathered focuses on parents' perspectives. We are only aware of one paper that focuses on the lived experiences of teachers working in special education. Rachel K. Schuck and Rachel Lambert [4] gathered data from two teachers working in special education. While it is not clear which country this data is collected from, the researchers' focus is on the shift to emergency remote teaching, which presented particular challenges to special educators of students with significant support needs who often benefit from strong interpersonal connections, modelling and the use of physical manipulatives.

In our research we were curious as to how teachers' living their 'teacher lives' during the first COVID-19 school closure in some ways not only challenged their engagement with students but also challenged their identity as teachers. A teacher's identity is multi-faceted, constantly growing [5], and dynamic within a diversity of contexts [6-8]. The COVID-19 lockdown disrupted the established facets of teacher engagement and challenged the contexts; hence, teachers' identities were questioned as they re-evaluated what was seminal in their role. Teachers' activities and engagement reflect the interactions of the elements of these contexts $[9,10]$. Sachs [11] argues that what teachers experience influences their thoughts about 'how to be', 'how to act' and also 'how to understand' (p. 15) their work and therefore their identity. Wenger's [12] writing on the negotiation of the self within a community of practice discusses the link between identity and practice as inextricable. The COVID-19 lockdown has offered a dilemmatic context where the processes of teaching and learning and being(s) a teacher are being re-visited and renegotiated.

This paper uses 'practical wisdom' (also known as phronêsis) as its theoretical basis. It will draw upon analysis of the two in-depth interviews within this theoretical framework.

\section{Scottish Context}

In this short section we give a very general overview of special education provision in Scotland and give context to the COVID-19 lockdown.

Scotland follows the standards set by the United Nations (UN) Convention on the Rights of the Child [13] through the Children (Scotland) Act [14], which guarantees that the Scottish Government is committed to developing a more inclusive society where every person has the opportunity to develop their skills and to participate in society. This implies that all children and young persons living in Scotland have an equal opportunity to achieve excellence, to have the highest expectations set for them and to have their achievements valued in the environment which suits them best. All children and young persons have an entitlement to a curriculum based on the principles of breadth, balance, progression, continuity and coherence [15]. Within this discourse some students with disability are supported by specialised provisions, where mainstream schooling cannot sufficiently support their educational achievement and wellbeing. These specialised provisions are multi-agency and have an array of services aimed at supporting students and their parents, 
with teachers specialised in supporting students with disability as their main point of contact. The paper focuses on the perceptions of two teachers working in this provision.

In March 2020 [16], the Deputy First Minister and Education Minister, John Swinney, highlighted that teaching, learning and support would continue, but differently, with teachers connecting with pupils through distance and online learning. It was established from the outset that children of key workers would be able to go to a local hub centre while their parents were at work during the normal school hours. The other pupils would be at home with their parent or carer and the rest of their family, with the teachers communicating with them from a distance. The Depute First Minister highlighted that vulnerable children would "not be cut adrift" [16] (no page number) and that there would be as much educational continuity as possible. This would all be ensured by enabling local authorities to have flexibility in their strategies [16].

\section{Methodology}

This paper draws from a qualitative study that was conducted during the COVID-19 lockdown in Scotland. As past teachers in schools and special schools and current trainers of teachers-indeed, as parents of children who attend schools-we had an awareness of the growing activity in schools in March 2020 as school closure was increasingly imminent. We were motivated to capture others' experience of this, especially those professionals in education whose working lives and pedagogical approaches were being disrupted by the pandemic. There was an urgency to do this as we wanted to gather the views of teachers while the situation was unfolding, as opposed to interviewing them in retrospect.

We, the authors, are part of a larger group of researchers from the School of Education and Social Work at the University of Dundee, all of whom were keen to capture the impact of this unique time on the lives of children, their families and educators. A decision was taken to carry out qualitative research with teachers and Head Teachers working in Scottish primary schools, focusing upon narratives and detailed insights into the lived experiences of teachers who had volunteered to be interviewed. We could not ethically gather more data than we could realistically manage to analyse, although the availability of it was tantalising. Reluctantly, we made the decision not to pursue the stories of educators in secondary schools or those of families and children themselves for this particular study but we recognise the need for further research with these groups.

Following ethical clearance from the University of Dundee, teachers and head teachers in primary schools in Scotland were invited through different social platforms to participate in an in-depth interview to capture their lived experiences in real time. Sixty teachers volunteered to participate in the research. These online interviews were carried out through MS Teams, starting from the second week of lockdown until the end of the scholastic year in June 2020 (each interview lasted between 30-90 min). Out of the 60 interviews only two teachers reported that they worked in special education. Coincidentally both teachers worked with children on the autism spectrum. As we described in the previous section, there are few special schools in Scotland, and thus teachers in special schools have a minor voice. This paper captures the minor voice of these teachers who are very often marginalised within a larger inclusive discourse [17].

The research aimed at gathering the teachers' understanding of their experiences and the impact of these on their identity as teachers. What were teachers' perceptions of their current experiences of work and how did they reflect on what they valued in their teaching and learning as they supported children and families during the lockdown? The participants who volunteered to be interviewed reported that they relished the opportunity to pause and reflect on their experience and also to appreciate the numerous ways in which they adjusted to the changes in their lives and their practice in a short span of time and under intense pressure. Nine questions guided the interviews, with the interviewers reporting that most participants needed little prompting as they were very articulate and fluent. The interview questions were chosen by the research leads with a view to prompt conversations covering the whole experience of the sudden lockdown and the 
slow realisation of the implications of the lockdown. As Hayes writes about her research, "they were interviews which took the form of conversations, but in which I made sure that the conversation covered half a dozen specific points" (p. 103). These questions were reviewed by critical colleagues interested in supporting the project and were then reviewed by two primary school teachers. Feedback was given as to the relevance of the questions, the language used and the sensitivity of the issues raised. The questions are listed as an Appendix A at the end of this paper.

The research group was not seeking a representative sample of educators in Scotland according to geographical and socio-economic contexts, as the aim was to capture the educators' personal thoughts about their experiences. We did not aim to generalise our findings across the primary sector on the basis of sample representation. In this kind of research, as Wendy Hollway [18] suggests, "generalizability ... has to be established according to theoretical rather than statistical principles" (p. 16). In the Rogerian sense that what is most personal is most general, we believe that the issues emerging from our process of analysis (explained below) are generalisable conceptually and theoretically. When disseminating our research findings in online seminars, we have had feedback that viewers have resonated with the participants' expressed thoughts and feelings [19] (p. 26).

The qualitative approach used in this study was deliberate given the social constructivist and shared experience environment in which we found ourselves. The rapidly changing educational environment was, in essence, being interpreted through the conversation between researcher and participants and is most identifiable as case study narrative [20]. The rich conversation provides thick descriptions of the experiences of the participating teachers allowing for many narrative threads to emerge. Our process of engagement with the transcripts was in essence a verbal and collaborative constant comparative methodology [4] and theory-led analysis. This process is further explained in the following paragraph. A number of themes emerged during our reading, discussing and re-reading of the interview transcripts and these are addressed under two main headings. The first is attentiveness and juggling elements of life such as dealing with uncertainty, being reflexive with children and families and juggling home and school. The second is attentiveness with regard to innovating with resources and adapting pedagogies for learning and teaching. Threaded through these two layers of analysis, the two teachers draw on professional knowledge, character and identity in order to respond with the highest possible sensitivity and effectiveness. The theory to which we frequently returned in discussing these themes was that of phronêsis. Indeed, not only did our identified themes point towards phronêsis but the reading of phronêsis impacted on our understanding and interpretation of the data.

The process of analysis can be visualised in the form of two spirals which seem to weave closer and closer together as they progress. These are constituted by our reading of various authors' writing about phronêsis and our listening to and transcribing of the interviews of these two teachers working in special schools. As we discussed the interviews together, it became evident that we were all struck by the thoughtful decisions and judgements that the teachers were taking to adapt to the unfolding situation of teaching from home. Although we have written about educational and professional issues referring to phronêsis, we re-visited our reading and found new authors, while at the same time becoming more and more immersed in the data. As Hollway and Jefferson [21] stress, "after a whole day working on the transcripts (a process we often referred to as 'immersion') we would be inhabited by that person in the sense that our imagination was full of him or her" (p. 69). We met online several times to discuss our thoughts about the literature read and the interviews, and started to explore themes that emerged, following Hollway's idea that the significance of the interviews is not only "a property of the extract, but of the work it is put to do" [18] p. 36. The themes emerged from our discussions with each other, as we related the teachers' responses about thoughtful judgments to our readings about professional judgment and phronêsis. We emphasise that the interview questions were set to elicit narratives of the initial lockdown, and we thus did not feel bound to them when fixing on themes. This was thus a theory-led thematic analysis [22] referring to phronêsis, 
where both theory and interviews were "speaking" to each other while at the same time challenging each other. This influenced the structure of this paper, with no distinction between findings and discussion, but rather themes with merging data and theory, thus "making complex" the lived experiences of these two teachers from special schools. In fact, our analysis focused on the attentiveness that the teachers' responses showed in two major aspects: the need to manage all the different factors in their changed lives, and their teaching and the children's learning. This is explained in the next section.

An illustration of this within the section entitled 'Attentiveness: juggling things' is where the theme is developed from a number of ideas that are amalgamated together: the personal life experiences of the two teachers, both parents of children that need additional support, as well as drastic changes in their lives due to the pandemic; this was linked to how these two teachers immediately related their personal experience to all children and in particular the children they work with.

\section{Acting with Phronêsis}

This section introduces phronêsis as our theoretical framework. We do so by indicating how the context of the research project was one in which phronêsis was very much warranted, and then provide literature on how some writers thought about phronesis within education. We do this to narrow the distance between theory and its application, as indeed is the end of the virtue of phronêsis.

The Scottish educational system has a multitude of policy documents which outline policies and procedures, as well as definitions and codes of ethics, which construct being a teacher and schooling. They are a necessity in a system of mass schooling. A document, such as a policy, is institutionalised at a given time and practitioners are not expected to dialogue with it, but to comply with what it says 'and sometimes there are penalties attached to failure to comply' [23] p. 392. Teachers can experience such policies and procedures in various ways and this sometimes means that they encounter limitations and tensions in them. The negotiation of such tensions, and possibly contradictions, in their practice involves what Aristotle termed phronêsis, a virtue which involves 'think[ing] about what concerns actions and how we ought to perform them' [24] p. 40. Thus, phronêsis is not knowledge in itself, but is the capacity to act, where its focus is the process that is 'concerned with how knowledge and experience are brought to bear in particular situations' [25] p. 3. It is the capacity 'to see' and be sensitive to a situation, discern, deliberate, reflect, judge and act [26].

A teacher does not always draw upon phronêsis in her work. Aristotle mentions epistêmê as the (scientific) knowledge a teacher uses in her work, (for example, knowledge on how children learn or child development), while technê refers to craftsmanship, technical knowledge, or art (such as that learning pedagogical skills employed when preparing for and delivering a lesson). These do not involve the person's character when they are drawn upon, so that the person, the teacher in our case, does not have to 'discern' [26] when using epistêmê or technê. 'It is the work of phronêsis to coordinate the division of labour between the different virtues within the individual' [27] p. 708. When epistêmê or technê are given predominance, action proceeds from the evidence at hand; the action is ready-made and does not require professional judgement. In fact, it involves following a procedure.

The closure of the physical school due to the pandemic has rendered null, albeit maybe temporarily, many of the policies and procedures mentioned in the beginning of this section. Teachers and head teachers have found themselves in a situation which is unprecedented and which does not fit any of the moulds which they are accustomed to have shaping their work. Along with the rest of the population, they have had to learn to live with the uncertainty that the COVID-19 pandemic brought to the world. The interviews highlighted the uniqueness of the situation that the teachers lived through in those first few days after school closure, as teachers struggled to find words to accurately describe.

"what it was like, we didn't know what we would be doing. And that was a weird day. I actually felt that day, like somebody had died ... I said to my friend, it's like grief 
because we didn't really know what was happening and we've been working with children in the classroom up to the Friday and then all of a sudden on the Monday we're told: wear gloves, keep $2 \mathrm{~m}$ apart. Yet we'd been in the school on the Friday as normal, so that was really scary" (Interviewee).

We could say that this situation was one in which phronêsis was very much warranted. As Nixon [28] writes, professional judgement 'comes into play at precisely those points where common sense guidelines are unclear and the criteria open to multiple interpretation' (p. 30) In fact this situation is as close as one could get to a laboratory situation where the impact of one function is measured with all possible confounding variables removed. All the physical trappings of space and time in a school which support and bolster a teacher were eliminated without much warning, and teachers had to rely on their own initiative, resourcefulness and judgements. This is where some teachers could be seen exercising judgement, by asking: what should I do in this constantly changing situation? As an ethical project, phronêsis 'allows the person who has phronesis- the phronimos-to be able to ascertain what is good for humankind and then deliberate about how best to reach that good' [29] p. 279. The ethical nature of this does not involve only 'knowledge that directs ethical action, but knowledge that must itself be constantly protected and maintained by good character' [30] p. 227. Therefore, phronêsis and character are not prior to one another, but they are in coordination to develop and shape each other. 'To be able to engage in phronêsis that is informed by 'ethical goodness', the phronimos must already have a character that is informed by and is coexistent with ethical goodness' [29] p. 280.

Those of us who have teaching experience know that teaching and being with children already presents us with complex and uncertain circumstances that are often in 'tension with one another' [31] p. 227. Everyday actions call for teachers' judgements, particularly in their daily practices within an educational discourse that often is imbued with terms such as 'outcomes', 'accountability', 'measurement', 'consistency' and 'certainty'. The difference between policies, procedures and the like and the teacher engaging in daily complex practices is that the former are 'determined outside of the activity to be selected and 'applied" [31] p. 228, while judgements are embedded in and through teachers' doings. Therefore, a teacher's practical judgements 'occur as part of teaching in ways that are similar to how judgement is arrived at when we face ethical dilemmas' [31] (p. 223-224). This kind of discerning and judgement become habitual, and yet their frequent use is done cautiously, thus preventing the judgement from becoming procedural $[32,33]$.

These two main factors, character [34] p. 330, [31] p. 225, and experiences which include an understanding of everyday complex situations [31] p. 224, [35] p. 589, [24] p. 18 , are what contribute to a teacher's practical judgements. What is yet fundamental within these two factors is the teacher's 'attentiveness' [34] p. 333 within her attention. It is not enough to attend, but to attend attentively. Aristotle refers to this as 'developing an eye' [30] (p. 368) within complex daily situations. Joseph Dunne [30] writes of 'the need [for teachers and educators] to develop even greater moral sensitivity rather than a closed deductivist code' (p. 310). The teaching situation, according to Dunne [30], is complex, has fluctuating forces at work within it, 'and hence the dynamic character of what it puts in play between teacher and students. There is always something at stake for the teacher and the students, so that success-defined largely by the goods of the subject but conditioned by the complexities of the situation-is never guaranteed' (p. 366). The attentiveness, written in Smith [34], that is being advocated here is one that needs to function with the performative school structures that mark our present educational systems. The teacher's judgements are a manifestation of her attentiveness to particular situations. This also has a political dimension. The teacher's 'judgement needs to be brought to bear on the rules and institutions themselves. From time to time they need to be challenged, revised and reorganised, and often that will be in the light of our awareness or practical cases for which they are inadequate' [34] p. 335.

Thus, what teachers 'do' during COVID-19 lockdown is at the heart of this paper. The uncertainty brought about by this unprecedented situation makes us think again about 
practices which have become procedural; indeed, uncertainty makes us better professionals because it makes us judge afresh [36,37]. Teachers who have rolled back their sleeves and attempted to grapple with teaching during lockdown have engaged with uncertainty, and asked 'what should I do in this constantly changing situation?' By accepting and understanding uncertainty and the fear which normally accompanies it, there is a move from technê towards phronêsis, that reasoning 'acquired by practitioners who, in seeking to achieve the standards of excellence inherent in their practice, develop the capacity to make wise and prudent judgements about what, in a particular situation, would constitute an appropriate expression of the good' [26] p. 426. In phronêsis their thinking 'is characterised by sensitivity to situated particulars and concrete cases, and by flexibility; [phronêsis] is the property of people of a certain character, who have relevant experience and know how to use it wisely' [38] (pp. 166-167). Thus, since, as mentioned in the previous paragraph, a teacher's judgements are a mark of her attentiveness, capturing moments of her attentiveness sheds a light on that teacher's judgements. Teachers' judgements in this doing and their thinking of these in unprecedented educational contexts will be explored in the next section, which reveals moments of attentiveness that these two teachers demonstrate to their particular situation, and how this attention challenges them, their work and their identity.

\section{Results and Discussion: Moments of Attentiveness}

In this section we discuss the ideas that emerged from the two interviews. We have given the fictitious names of Carmen and Grace to the teachers. Two themes will be discussed, both trying to give an understanding of these two teachers' attentiveness.

\subsection{Attentiveness: Juggling Things}

Grace has been a teacher over twenty years. She has worked in mainstream classrooms and also in various special educational settings. One of her own children has additional support needs. Carmen has been a teacher for five years. She also worked in a mainstream school for a short time, is now a teacher in special educational settings, and has a child with additional support needs. Carmen expressed that having her children at home 'means that you've got to support them in their learning and one of my children has additional needs herself. So, she needs a lot of one to one support to access any of the learning that has been provided for her'. Both teachers spoke of the tension of finding a 'balance' (Grace) between family life and their teaching. This tension for Carmen is a constant juggle: 'I'm just juggling things. I suppose, juggling work and family life. You know, they're all taking place in the same house. It's, yeah, that's been tricky'. Carmen's words describe the challenges presented by the blurring of the boundaries between the school space and time and home space and time. Anne Edwards [39] reminds us that boundaries are social constructions 'which define who is included and excluded from interactions and which knowledge or meaning system is considered relevant in those interactions' (p. 43). Working in COVID-19 lockdown has not only brought into question who is included but also where power lies in interactions. The human element of the 'professional teacher' which, in the case of Carmen and Grace, included being mothers, has become enmeshed in a more pronounced way during lockdown. However, these two teachers react differently to this. For Carmen they are a tricky juggle:

Carmen: So sometimes it's in the evenings, because I'll need to be spending time with my children during the day and we have had problems accessing the system as well because it was overloaded because everybody's working from home. So to begin with, we weren't able to access the system between 8:00 and 4:30 anyway, so I was doing a lot in the evenings: planning and tracking. And the other day to day things that you do as a teacher that people probably don't realize indeed.

Interviewer: And that usually happens after your own children have gone to bed?

Carmen: Absolutely! Yes, yes. 
Grace tackles this differently:

Some people are saying, that I'm going to do my blog and my emails in the morning and I'm going to do my own things in the afternoon. I personally, I have to do my own, uhm, my Google Calendar and I block it out. So like 12 to $2.00 \mathrm{pm}$, I'll say that's my lunch exercise time, 2:00 till 4:00 I work on my assessment time, 5:00 till 6:00 is my knitting. I'm quite methodical, I quite like to work like that.

Interestingly, when Carmen and Grace describe their juggling and attempts to find balance in their lives, this conversation flows naturally into the lives of school children they work with. Carmen recounts that her daughter is upset as her mother is 'out of her normal routine and is having to do work jobs at home. Which obviously is not what [the daughter] associates home with, so that's been really tricky'. In the interview, Carmen's response flows without a pause to the 'trickiness' that families of children she works with encounter when they try to engage their children with additional support needs with the work Carmen provides. She immediately related her personal experience to all children and in particular the children she works with (' . . that's probably difficult for any pupil, but especially ours') as she describes that this is a struggle that these families have, as children associate the work set by their teacher with being in school. There is a natural flow in Carmen's thoughts to move from 'her daughter' to 'our children'. This had already been researched and written about in the past: Grumet [40] argues that teachers accord their school children much the same rights as they do their own children; Pat Sikes [41] p. 76 reports that many of the parent-teachers in her study felt that their feelings of care and love for the children in their classes became more intense when they had their own children. Yet this lockdown has intensified these thoughts and feelings because of the blurring of these boundaries $[42,43]$. The teachers' character, their habits, inform their decisions and actions, which lead to experiences which in turn contribute to the continuous formation of character and habits. There is an awareness of a telos to be worked for, but also an awareness that one encounters the good also on the journey towards that ideal. Carmen and Grace are both juggling claims on their time and 'attention' - they keep their school children in mind, they keep their parents' struggle in mind, and they also keep in mind their own children and their own struggle. 'It's going to be too tricky for their parents to do. And it doesn't always work' (Carmen). Carmen feels the same conscientiousness towards other children as her own and alongside her attempts to always do better, she also has the thought 'I will do what I can as much as I can'. She has the awareness that it may not all be smooth and packaged. She strives to make it so and is at the same time not debilitated by the knowledge that it cannot be so. It can perhaps be explained by Jenny Corbett's writing in which she finds teaching and caring 'synonymous'. She talks of " careful teaching", [that is] not separating the care from the teaching' [44] p. 237.

It also came across during the interviews that these two teachers reflected at various moments on the current situation. They were very much in touch with their own ideas and reasoning, and acknowledged the limitations of their actions in the moment. The lockdown seems to have allowed for the limitations of their actions to emerge and they were able to live with them and be fine with them. An element of guilt, because they were not doing as much as they wanted with their own children and their school children, was hinted at in the interviews. This allowance of limitations was certainly not the case prior to lockdown where teachers were held accountable at many levels. The teachers' past experiences and knowledge of the students helped them discern those fundamental aspects that needed to be maintained during lockdown.

\subsection{Attentiveness: Learning and Teaching}

It is important to situate that these two teachers were interviewed around 6 weeks from the start of lockdown, which included a two-week Easter recess where the teachers were not engaged in online learning. Grace spoke of the experience of working in lockdown as 'chaotic'. This chaos needs to be contextualised as we think it captures the urgency, rapidity and uncertainty that these two teachers worked in, which is a very different 
experience from the classroom/school environment that projects some level of control from the part of teachers. From reading the data we think that the issue of timing is related to the issue of learning and teaching that this section focuses on.

Grace stated that 'We did send out [learning] packs beforehand. I think we had one day's notice and I literally just went around my classroom gathering old worksheets that I've got and I had enough to make up 9, I've got nine children in my class ... and just made up these packs for them at home, and some parents are still just working through those packs'.

On the Monday that was the first day of lockdown, Grace together with the other teachers and classroom assistant were asked to go in to school. She talked about this in a very powerful way (quoted above) that captures this uncertainty and lack of knowledge, using words like weird, like grief, like somebody had died, scary.

After this initial stage, both teachers talked about becoming accustomed to using technology to start sharing learning materials with the children and their families. Grace highlighted that the Local Authority, prior to COVID-19 lockdown, had intended to start engaging teachers and educators with technology: 'I think there was an email sent out in February about everyone, emm, using MS Sway and using blogs, and I'm not sure if the IT department in the Local Authority knew before we did, but I don't think anyone looked at that email. I certainly didn't. I didn't have time I was teaching ... we've always done things face to face'.

When asked about their engagement with online teaching, Grace and Carmen replied that they use platforms such as blogs, MS TEAMS or MS Sway 'which I've just learned how to use' to 'put up activities, links to videos, link to subscriptions and photos'. Both teachers commented that they were not given permission to have face-to-face sessions with the children and families. Carmen reflected on this and she thinks that while some students could benefit from face-to-face sessions, she 'know[s] that some of [the children] have reacted badly to videos because they don't like seeing us on the screen. Others absolutely love it and just watch them over and over and over again. But it really depends on the child'.

Carmen explained that her daughter taught her how to create videos. Grace had a different narrative. It seemed that some pressure was exerted by 'the younger teachers' on their colleagues to develop videos and share these with the children and their families. She felt that 'that there's a bit of pressure' because there were teachers who were 'making their own videos for families'. Grace felt a little 'bit stroppy about it'. She settled on making audio casts only. Grace reports that she did not succumb to the pressure of following her colleagues who were filming videos. However, during the interview, almost in a reflective stance she did question herself and say 'Emm, but half of me then thinks I should be doing it, so I've never taught like that ... If I was doing maths I could use things around the house [to do a video], but then it's just adding to your day really. I think we have to balance'. Grace mentioned several times during the interview that some teachers were 'very competitive' amongst themselves about what they were posting online during the first week of teaching. Grace is able to pause and reflect on this: 'It got really quite funny and in the second week I was in the hub [In Scotland, during lock-down care-centres for children of key workers and vulnerable children were set up. These were called hubs and were located in schools and or day-care centres/nurseries] so I didn't see it. But I think people step back a bit. Then we've had the two weeks holiday and people have said, 'right ... ', and they've done more work-life balance'. Carmen tried to post a small video message every day. She even encouraged her support staff to 'send me videos saying hello to all the pupils so we're keeping in touch that way'.

Apart from posting online materials, emailing students and their families and attending to their replies was deemed important as a way of monitoring the students and their families. 'If nobody has replied by the Friday, we tend to get them, give them a phone call and if they haven't found by then we then highlight it to see the management and they 
then contact social work'. Similarly, the online platforms enabled teachers to see whether the resources posted have been accessed by the children and their families.

Even if every student is unique in the respective school contexts of these two teachers, both were instructed by their different schools not to differentiate their work to the needs of particular students. They were suggested 'to try and do a rough average' and in particular 'sending home any new learning ... it's more about consolidating what the children already know and building on that'.

Carmen commented that the children who attend her school have an adapted curriculum. She emphasised that while numeracy and literacy are core, life skills are central to her student's learning, and 'communication is a massive, massive part of that, that's happening all the time, I suppose, these life skills. Actually, this is a great opportunity for the children to develop some of those life skills within their home setting'. Grace shared an example, that one of her students sent her a picture of himself cutting vegetables at home, part of his school life-skills targets.

Both teachers shared with us some examples of 'average' activities posted. Grace gave us an art example where she 'posted up about Andrew Goldsworthy, the artist... There's a little power point that went with it. There were some photos of his work and then it suggested they went out and collected some sticks and rocks and things to make their own pictures and then to post up a photo afterwards'. The focus of both teachers is to 'sort of linking in activities that they can do at home'. It seems that both teachers understand that there is a difference between 'home learning' and 'school learning'. Their expectations were not the same and somehow different. Home learning seems to be more about students being with other family members and enjoying what they are doing. There is constant echo from both teachers that activities posted are thought of in such a way 'that families could enjoy. All of them could enjoy'. There was also mention that siblings of children with disability and/or learning difficulties were involved: 'I got an email the other day from one of the children's sister. So I think the sister was helping, like a teenage sister. I think the teenage sister was helping out [her brother with a disability]'. This markedly different from learning in school where 'we work in a quite structured, obviously, our [school] days are very very structured. From the minute they walk in the classroom to the minute they leave'.

Both teachers spoke with a sense of urgency about the parents of the children they teach. Grace spoke that 'I think parents are just (emphasises the word 'just') surviving'. Similarly, Carmen explained:

Some of the boys in my class are quite big, bigger than their parents and they can get quite distressed and become quite aggressive, which is so in that sense, I think pretty much every family that I work with falls into a vulnerable category just because of the significant needs of the children really.

Research around parents of children with disability is extensive. In 2011, Contact a Family [45] researched the effects of isolation on parents of a child with disability and found that $65 \%$ of families felt regularly or continually isolated. This is also supported with a more recent study by Holland, Pell and KIDS [46].

It is also very evident that both teachers are aware that different students may not have the resources at home: 'sort of linking in activities that they can do at home and with resources that they have or haven't got because, obviously I don't know what they've got at home. If they've got paint, if they've got cookery ingredients, if they've got scissors, we are just finding out whether parents have got access to the Internet'. Not only are resources mentioned as a factor that could challenge accessing and engaging with online learning, but the teachers are aware that some parents and carers have difficulties with reading, or do not have the time to read to their children, or have mental health issues.

While there is planning and effort on the part of teachers to upload materials, Grace did emphasise that the learning going on in lockdown has 'been a bit hit and miss'. What also came across strongly is how both teachers miss being with their students and they 
'can't wait to get back into school'. It is this awareness of this that we think is central to the theme discussed.

We query what influence class and school teaching had on online home teaching and learning. Both teachers seemed to experiment, and they used their judgement in the moment. This becomes interesting when considering the element of time which has been a very significant factor during the lockdown. Situations were changing constantly. Codes of practices formulated by Scottish Government, interpreted by the Local Authorities and subsequently by head teachers, were very fluid (and continue to be) and changed at a fast pace. The interviews of both teachers reflected their judgements in interpreting these codes of practice in relation to their school children. Such judgements informed their working with other teachers, or people within their school's administration team, as well as parents and children within their schools. With regards to online learning, there were moments when classroom practices were mimicked online. However, both teachers were quick to adapt their ways of doing and not only learn new technology but also question the concept of learning that that is so inherent in their identity. We think that this requires Grace and Carmen to continually judge the moment, the circumstances, and their actions and thinking on this.

\section{Conclusions}

The COVID-19 pandemic seems to have seen a diminishing of the distinction between the practice of work and the practice of life of these two teachers. Both teachers seem to be on a journey to make the lives of the students they work with, as well as their own lives, 'better'. This paper is significant in that it highlighted the impact of the unprecedented phenomenon on these teachers. The uniqueness of the situation acted like a pause in the daily routine of this 'runaway world' [47] and this slowing down has enabled the research to have a glimpse of the minutiae of being a teacher in special education. Viewing this through the lens of phronêsis has allowed us to see how the teachers' values have influenced their practice, through the judgments and decisions made. It has also highlighted the carry-over between a teacher's personal life and her professional life, as the teachers' own experiences had an impact on their perspectives of the families whose children they taught. This is particularly needed for teachers in special schools, whose voices and experiences are not very prominent in education. In a world that values outcomes and measures success as the reaching of targets, this paper aims to enable us to think again about what makes a professional-that is, the judgments reflecting how these teachers adapted their principles, experiences and values to the contingencies of the moment. It aims to shed light on these, as they will not be captured by any instrument which measures.

The teachers' many small moments of attentiveness to the unique situation provided by the COVID-19 pandemic called for them to make judgements where guidelines and procedures were often unclear and constantly changing, and criteria open to multiple interpretation. We recall Wenger's [12] writing about the link between practice and identity and we believe that this experience, and possibly also the chance to reflect through being interviewed, may have contributed to further knowledge about themselves as teachers. Their attentiveness has enabled them to reflect on what is important in their identity of being a teacher, namely as having a caring role for students and their families.

Author Contributions: Conceptualization, D.M., D.P.M. and K.W.; methodology, D.M., D.P.M. and K.W.; formal analysis, D.M., D.P.M. and K.W.; data curation, D.M., D.P.M. and K.W.; writingoriginal draft preparation, D.M., D.P.M. and K.W.; writing-review and editing, D.M., D.P.M. and K.W. All authors have contributed equally in this paper. All authors have read and agreed to the published version of the manuscript.

Funding: This research received no external funding.

Institutional Review Board Statement: The study was conducted according to the guidelines of the Declaration of Helsinki, and approved by the Institutional Review Board (or Ethics Committee) of University of Dundee (protocol code E2019-83 and date of approval 3 April 2020). 
Informed Consent Statement: Informed consent was obtained from all subjects involved in the study.

Data Availability Statement: The datasets presented in this article are not readily available because the dataset is only available to the research team. Requests to access the datasets should be directed to corresponding author.

Conflicts of Interest: The authors declare no conflict of interest.

\section{Appendix A. Interview Questions}

Research Question: What are educators' experiences of teaching from home/in hub during the COVID-19 lockdown in Scotland?

1. A little about yourself

2. What about your class?

3. What is your role as a teacher during this lockdown? Are you supporting home learning, or are you supporting children in a hub?

4. How has this experience affected your ideas of teaching, learning and curriculum?

5. How have you adapted to this new teaching situation?

6. What learning have you tried to focus on with your class? How far ahead can you plan or are there key areas on the horizon?

7. Can you provide an example of something that was challenging and something which was relatively easy.

8. What is the role of parents/carers in learning during this lockdown?

9. What are your thoughts about the impact of this on pupil transitions?

\section{References}

1. United Nations Disability-Inclusion Response to COVID-19. 2020. Available online: https://www.un.org/sites/un2.un.org/ files/sg_policy_brief_on_persons_with_disabilities_final.pdf (accessed on 20 June 2021).

2. Couper-Kenney, F.; Riddell, S. The impact of COVID-19 on children with additional support needs and disabilities in Scotland. Eur. J. Spec. Needs Educ. 2021, 36, 20-34. [CrossRef]

3. O'Connor, U.; Bates, J.; Finlay, J.; Campbell, A. Parental involvement during COVID-19: Experiences from the special school. Eur. J. Spec. Needs Educ. 2021, 1-14. [CrossRef]

4. Strauss, A.; Corbin, J. Basics of Qualitative Research Techniques and Procedures for Developing Grounded Theory, 2nd ed.; Sage Publications: London, UK, 1998.

5. Dewey, J. Democracy and Education; Echo Library: Teddington, UK, 2007.

6. Beauchamp, C.; Thomas, L. Understanding teacher identity: An overview of issues in the literature and implications for teacher education. Camb. J. Educ. 2009, 39, 175-189. [CrossRef]

7. Beijaard, D.; Meijer, P.C.; Verloop, N. Reconsidering research on teachers' professional identity. Teach. Teach. Educ. 2004, 20, 107-128. [CrossRef]

8. Danielewicz, J. Teaching Selves: Identity, Pedagogy, and Teacher Education; University of New York Press: New York, NY, USA, 2001.

9. Olsen, B. Teaching What They Learn, Learning What They Live; Paradigm Publishers: Boulder, CO, USA, 2008.

10. Sfard, A.; Prusak, A. Telling identities: In search of an analytic tool for investigating learning as a culturally shaped activity. Educ. Res. 2005, 34, 14-22. [CrossRef]

11. Sachs, J. Teacher Education and The Development of Professional Identity: Learning to be a Teacher. In Connecting Policy and Practice: Challenges for Teaching and Learning in Schools and Universities; Denicolo, P., Kompf, M., Eds.; Routledge, Taylor and Francis Group: Oxford, UK, 2005; pp. 5-21.

12. Wenger, E. Communities of Practice; Cambridge University Press: Cambridge, UK, 1998.

13. United Nations Convention on the Rights of the Child. 1989. Available online: https://www.ohchr.org/EN/professionalinterest/ pages/crc.aspx (accessed on 20 June 2021).

14. Children Scotland Act. 1995. Available online: https://www.legislation.gov.uk/ukpga/1995/36/ contents (accessed on 20 June 2021).

15. Education Scotland. 2019. Available online: https:/ / education.gov.scot/ (accessed on 20 June 2021).

16. Scottish Government. Coronavirus (COVID 19)—Supporting Pupils, Parents and Teachers-Learning during Term 4. 2020. Available online: https://www.gov.scot/publications/supporting-pupils-parents-teachers-learning-during-term-4/ (accessed on 20 June 2021).

17. Riddell, S. Social justice, equality and inclusion in Scottish education. Discourse 2009, 30, 283-296. [CrossRef]

18. Hollway, W. Subjectivity and Method in Psychology: Gender, Meaning and Science; Sage Publications: London, UK, 1989.

19. Rogers, C. A Therapist's View of Psychotherapy_On Becoming a Person; Constable: London, UK, 2001. 
20. Yin, R.K. Case Study Research: Design and Methods; Sage Publicatitons: London, UK, 2014.

21. Hollway, W.; Jefferson, T. Doing Qualitative Research Differently; Sage Publications: London, UK, 2000.

22. Hayes, N. Theory-Led Thematic Analysis: Social Identification in Small Companies, Doing Qualitative Analysis in Psychology; Psychology Press: London, UK, 1997.

23. Small, R. Codes are Not Enough: What Philosophy Can Contribute to the Ethics of Educational Research. J. Philos. Educ. 2001, 35, 387-406. [CrossRef]

24. Ameriks, K.; Clarke, D.M. Aristotle The Nicomachean Ethics; Penguin Classics: London, UK, 2004.

25. Halverson, R.; Gomez, L. Phronêsis and Design: How Practical Wisdom Is Disclosed Through Collaborative Design. In Proceedings of the American Educational Research Association Annual Meeting (AERAA), Seattle, WA, USA, 20 April 2001. Available online: http:/ / www.education.wisc.edu/elpa/people/faculty/halverson/HalversonGomez\%20AERA\%202001.pdf (accessed on 10 September 2020).

26. Carr, W. Philosophy, Methodology and Action Research. J. Philos. Educ. 2006, 40, 421-435. [CrossRef]

27. McPherson, I. Reflexive learning: Stages towards wisdom with Dreyfuss. Educ. Philos. Theory 2005, 37, 705-718. [CrossRef]

28. Nixon, J. What is Theory? Educar 2004, 34, 27-37. [CrossRef]

29. Noel, J. Phronesis and Phantasia: Teaching with Wisdom and Imagination. J. Philos. Educ. 1999, 33, 277-286. [CrossRef]

30. Dunne, J. Back to the Rough Ground: Phronesis and Techne in Modern Philosophy and in Aristotle; University of Notre Dame Press: London, UK, 1993.

31. Doddington, $\mathrm{C}$. The global search for better teaching: How should teachers think for themselves? Education 2013, 41, 218-232. [CrossRef]

32. Attard, S.; Mercieca, D.; Mercieca, D.P. Educational psychologists' report writing: Acts of justice? Int. J. Incl. Educ. 2016, 20, 962-974. [CrossRef]

33. Mercieca, D.; Mercieca, D.P. Judgements on young children by Early Years practitioners: Working with phronêsis. Int. J. Incl. Educ. 2020, 24, 1431-1443. [CrossRef]

34. Smith, R. Paths of Judgement: The revival of practical wisdom. Educ. Philos. Theory 1999, 31, 327-340. [CrossRef]

35. Nyberg, D. The Morality of Everyday Activities: Not the Right, But the Good Thing to Do. J. Bus. Ethics 2008, 81, 587-598. [CrossRef]

36. Mercieca, D. Working with uncertainty: Reflections of an educational psychologist on working with children. Ethics Soc. Welf. 2009, 3, 170-180. [CrossRef]

37. Mercieca, D. Beyond Conventional Boundaries: Uncertainty in Research and Practice with Children; Sense Publishers: Amsterdam, The Netherlands, 2011.

38. Smith, R. As if by machinery: The levelling of educational research. J. Philos. Educ. 2006, 40, 157-168. [CrossRef]

39. Edwards, A. Being an Expert Professional Practitioner; Springer: New York, NY, USA, 2010.

40. Grumet, M. Bitter Milk: Women and Teaching; The University of Massachusetts Press: Amherst, MA, USA, 1988.

41. Sikes, P. Parents Who Teach: Stories from Home and from School; Cassell: London, UK, 1997.

42. McLennan, C.; Mercieca, D.; Mercieca, D.P. What can I do? Caring relationships among teachers, students and families during COVID-19 lockdown in Scotland. Malta Rev. Educ. Res. 2020, 14, 163-181.

43. Ferguson, P.; Mercieca, D.; Mercieca, D.P.; Sutherland, L.; Mckenzie, M. Primary Head Teachers' construction and re-negotiation of care in COVID-19 lockdown in Scotland. Front. Educ. 2021, 6, 617-869. [CrossRef]

44. Corbett, J. Careful teaching: Researching a special career. Br. Educ. Res. J. 1992, 18, 235-244. [CrossRef]

45. Contact a Family Forgotten Families: The Impact of Isolation on Families with Disabled Children across the UK. 2011. Available online: https://contact.org.uk/media/381636/forgotten_isolation_report.pdf (accessed on 10 September 2021).

46. Holland, J.; Pell, G.; KIDS. Children with SEND and the emotional impact on parents. Br. J. Spec. Educ. 2018, 45, 392-410. [CrossRef]

47. Nixon, J. Professional Renewal as a Condition of Institutional Change: Rethinking academic work. Int. Stud. Sociol. Educ. 2003, 13, 3-15. [CrossRef] 